\title{
How to access and process FDA drug approval packages for use in research
}

FDA databases contain valuable information on unpublished studies, but it can be difficult to find. This article explains where to look and provides tips on how to make documents easier to use

\author{
Erick $\mathrm{H}$ Turner associate professor ${ }^{123}$
}

${ }^{1}$ Behavioral Health and Neurosciences Division, Portland Veterans Affairs Medical Center, Portland, Oregon, USA; ${ }^{2}$ Department of Psychiatry and Department of Pharmacology, Oregon Health and Science University, Oregon $;{ }^{3}$ Center for Ethics in Health Care, Oregon Health and Science University

Reporting bias leads to an overestimation of drug efficacy and underestimation of drug harms, but its effects can be mitigated by using unpublished data from drug regulatory agencies. Such data can be useful to clinicians interested in going beyond the product labelling and published literature. By comparing drug regulatory data with the published literature, researchers can uncover reporting bias, and researchers have been advised to use such data in systematic reviews ${ }^{1}$ and meta-analyses. ${ }^{2}$

The European Medicines Agency has been making clinical trial data available on request since November $2010,{ }^{3}$ and next year, notwithstanding legal challenges, it will expand access by making data publicly available for download from its website. ${ }^{45}$ Unlike, the EMA, the US Food and Drug Administration does not make individual patient data available. However, drug approval packages, also referred to as reviews or summary basis of approval documents, have been available on the FDA website since $1997 .{ }^{6}$ These are filtered summaries of clinical study reports and related documents, written by FDA staff, who may review "pivotal trials" in more depth than other trials.

Although regulatory data have been used in several studies, ${ }^{8-13}$ they are underused. A survey of authors of Cochrane reviews and protocols found that $97 \%$ failed to obtain data from regulatory agencies. ${ }^{14}$ This survey found many reasons for this, one of which was that the authors did not know it was possible to get them. An obstacle to the use of FDA drug approval packages may be that it is difficult to navigate to and within these documents.

Various publications have advocated the use of FDA data, ${ }^{1-20}$ but few have provided instructions for doing so. ${ }^{17}{ }^{21}$ Below, I provide a detailed, annotated procedure for accessing drug approval packages and suggest how to make them more easily usable.

\section{For what drugs can I find drug approval packages?}

Drug approval packages are available on the FDA website for drugs approved since 1997. ${ }^{72}$ Data on drugs approved before 1997 can be requested at the following link: www.accessdata. fda.gov/scripts/foi/FOIRequest/requestinfo.cfm. Unfortunately, it can take a long time to obtain a response, especially if the request involves more than one drug or is otherwise complex. Drug approval packages are often available only for the first indication approved and not for later indications. An example that has been pointed out twice previously concerns the atypical antipsychotics for bipolar mania. ${ }^{73}$ Nevertheless, substantial amounts of clinical trial data are available for download from the FDA website, the process for which is illustrated below.

\section{How do I navigate to the reviews?}

1. Start by going to the FDA home page (www.fda.gov) and clicking on the drugs tab at the top of the page (fig $1 \Downarrow$ ).

2 . On the right side of the following page (fig $2 \Downarrow$ ), click on the link to search for drug information (Drugs@FDA). This will take you to the main drug search page (fig $3 \Downarrow$, www. accessdata.fda.gov/scripts/cder/drugsatfda/index.cfm). Alternatively, you can find this page by entering "Drugs@FDA" into a search engine.

3 . Enter the drug name into the search field and press submit. In the example I have searched using the generic name venlafaxine, but it is often easier to enter a brand name. This is because the FDA's most rigorous review occurs before the drug is first approved for US marketing and using the generic name will bring up later reviews of generic drugs that focus on bioequivalence to the branded drug rather than efficacy and safety. 
4. Select the link corresponding to the drug of interest. In this example it is Effexor XR (venlafaxine extended release). Our search results (fig $4 \Downarrow$ ) include links not only for venlafaxine but also for another product whose name contains the search word (desvenlafaxine, the metabolite of venlafaxine, which was approved and marketed as a separate product).

5. The next page (fig $5 \Downarrow$ ) shows that Effexor XR was originally approved on 20 October 1997, so a review should be posted. Select the link for "Approval History, Letters, Reviews, and Related Documents"

6 . The following page (fig $6 \Downarrow$ ), shows the drug's approval history in reverse chronological order. The bottom row (not shown in fig 6), the earliest point in the approval history, is dated 20 October 1997, labelled "Approval," and includes a link for a review.

7. Click on review, which takes you to a page (fig $7 \Downarrow$ ) with links to various documents comprising the drug approval package: approval letter(s), medical review(s), chemistry review(s), clinical pharmacology review(s), and statistical review(s). For other drugs, there may be additional review types. ${ }^{19}$

8. Click on and download the desired reviews. (See below for explanation of uses of different review types, as only some of them will be of interest.)

\section{Can I obtain reviews for later approved indications?}

The links related to the date of approval will give data only for the originally approved indication (major depressive disorder). According to the product labelling, Effexor XR is also approved for generalised anxiety, social anxiety, and panic disorder. Scrolling upward in the approval history page, you can see rows labelled "New or Modified Indication"; each linked "Letter" states the indication approved. Unfortunately, only one such row also contains a link for "Review." Consequently, in order to obtain the FDA's review of Effexor XR for generalised anxiety disorder (approval date 11 March 1999), you must submit a freedom of information request (see step 2 above).

\section{Which review type should I use?}

Researchers and clinicians interested in drug safety in humans will find pertinent data in the medical review. Preclinical data, especially safety data from in vitro work and animals, can be found in the pharmacology reviews. Clinical pharmacology biopharmaceutics reviews cover topics such as receptor effects, dose-response relations, metabolic pathways, pharmacokinetics and how these are affected by demographic factors, comorbid disease, food, and other drugs. (To my knowledge, no researchers have made use of either of these review types to examine reporting bias in preclinical pharmaceutical research.) For Effexor XR, there is no pharmacology review, probably because this would have been reviewed for the original, immediate release formulation of the molecule.

Efficacy data can be found in the statistical and medical reviews, both of which are substantially longer than standard journal articles. Researchers should examine both medical and statistical reviews, especially if they were written during different review cycles, in which case the studies they cover could differ. For Effexor XR, the statistical review is 98 pages long. Medical reviews tend to be longer, because they cover safety as well as efficacy. For this drug, the medical review has been split into two PDF documents, part 1 (86 pages) and part 2 (98 pages). If desired, these can be combined into a single PDF document with PDF editing software.

As mentioned above, other review types may be available. For instance, for the antidepressant vilazodone, there is a link for administrative documents and correspondence. Documents with this title often contain memos from the team leader and other decision makers in the FDA hierarchy; for vilazodone, the document consists mainly of email correspondence between the FDA reviewers and the sponsor. Other links possibly worth exploring are the summary review, written by the division director, and the office director memo. As you go up the hierarchy from the primary reviewers to the team leader, the division director, and the office director, the reviews or memos tend to be briefer and focus on the decision whether the data presented in the (longer) primary reviews, on balance, support FDA approval.

\section{How can I make downloaded reviews more user friendly?}

Many of the documents on the website are not searchable because the FDA has printed them, redacted trade secrets and confidential information, ${ }^{6}$ and then scanned and converted them into images. ${ }^{23}$ Reviews for some newer drugs, such as vilazodone (above) have been redacted electronically, so that the documents remain searchable. Fortunately, the obstacles imposed can be worked around to some extent, albeit with substantial time and effort. $^{24}$

For example, if you have software capable of editing PDF documents, such as Adobe Acrobat (not to be confused with the free Adobe Reader), you can use optical character recognition to make the document (mostly) text searchable. You can then search the document for specific study numbers and bookmark the various places where each study is mentioned. Within the navigation pane, you can then rearrange the bookmarks into a hierarchical structure organised by study.

As an alternative to electronic bookmarks, you can print a hard copy of the review and sort the pages manually into a binder, with dividers for each study. Multiple copies may be needed of pages that cover two or more studies. It is advisable to number the pages (which can be done with PDF editing software, as well) before sorting. The original page numbering in the PDF is often confusing, making it hard to determine where a page came from once it has been divorced from its context.

\section{What information can I find within the drug approval package?}

The medical review should contain a list of all trials on a drug, although it is not always straightforward to find. Within part 1 of the Effexor XR medical review, a table of contents can be found on page 30 (of 86). This provides an overview of the conducted studies, and it refers to a table of studies on page 110. However, page 110 does not exist within this PDF document, but rather in part 2 of the review, pages 57-58 of 98 (fig $8 \Downarrow$ ). Here we find a listing of trials of various types, including phase 1 trials (which are not registered on ClinicalTrials.gov ${ }^{25}$ ) and controlled, as well as uncontrolled, trials of depression. This table can be regarded as equivalent to a registry of premarketing trials for the drug and indication in question. As with other registries, this can be used to identify trials that have not been published. You can then request data on them from drug companies ${ }^{26}$ or use the clinical trial results reported within the drug approval package. When my group 
took the latter approach with Effexor XR (and 11 other antidepressants), ${ }^{9}$ we found that one of the three main premarketing studies, study 367 , had not been published. Figure $9 \Downarrow$ is a table from the data approval package showing that the results on this study's primary outcome were not significant $(\mathrm{P}$ values of 0.37 and 0.14 for the two doses tested against placebo). Our awareness of these unpublished data allowed us to include them in the meta-analysis and revise this drug's effect size from 0.50 to 0.41 .

Competing interests: I have read and understood the BMJ policy on declaration of interests and declare I was previously employed as a medical reviewer at the US Food and Drug Administration. I have published essays and letters about use of FDA drug approval packages and used them as data sources in research articles.

Provenance and peer review: Not commissioned; externally peer reviewed.

1 McDonagh MS, Peterson K, Balshem H, Helfand M. US Food and Drug Administration documents can provide unpublished evidence relevant to systematic reviews. J Clin Epidemiol 2013 July 12 [Epub ahead of print].

2 Chan A-W. Out of sight but not out of mind: how to search for unpublished clinical tria evidence. BMJ 2011;344:d8013

3 Doshi P, Jefferson T. The first 2 years of the European Medicines Agency's policy on access to documents: secret no longer. JAMA Intern Med 2013;173:380-2.

4 PLoS Medicine Editors. Getting more generous with the truth: clinical trial reporting in 2013 and beyond. PLoS Med 2013:10:e1001379.

5 Steinbrook R. The European Medicines Agency and the brave new world of access to clinical trial data. Arch Intern Med 2012;1-2.

6 Committee on Government Reform, House of Representatives, 109th Congress, et al. A citizen's guide on using the Freedom of Information Act and the Privacy Act of 1974 to request government records. US Government Printing Office, 2005.

7 Turner EH. A taxpayer-funded clinical trials registry and results database. PLoS Med 2004;1:e60.
8 MacLean CH, Morton SC, Ofman JJ, Roth EA, Shekelle PG. How useful are unpublished data from the Food and Drug Administration in meta-analysis? J Clin Epidemiol 2003;56:44-51.

9 Turner EH, Matthews AM, Linardatos E, Tell RA, Rosenthal R. Selective publication of antidepressant trials and its influence on apparent efficacy. N Engl J Med 2008;358:252-60.

10 Rising K, Bacchetti P, Bero L. Reporting bias in drug trials submitted to the Food and Drug Administration: review of publication and presentation. PLOS Med 2008:5:e217; discussion e217.

11 Schwartz LM, Woloshin S. Lost in transmission-FDA drug information that never reaches clinicians. N Engl J Med 2009;361:1717-20.

12 Schwartz LM, Woloshin S. How the FDA forgot the evidence: the case of donepezil 23 mg. BMJ 2012;344:e1086.

13 Turner EH, Knoepflmacher D, Shapley L. Publication bias in antipsychotic trials: an analysis of efficacy comparing the published literature to the US Food and Drug Administration database. PLoS Med 2012;9:e1001189.

14 Schroll JB, Bero L, Gotzsche PC. Searching for unpublished data for Cochrane reviews: cross sectional study. BMJ 2013;346:f2231-1.

15 Bennett DA, Jull A. FDA: untapped source of unpublished trials. Lancet 2003;361:1402-3

16 Lurie P. Zieve A Sometimes the silence can be like the thunder: access to pharmaceutica data at the FDA. Law \& Contemp Probs 2006;68:85.

17 O'Connor AB. The need for improved access to FDA reviews. JAMA 2009:302:191-3.

18 Cook GE, Madden MM. The significance of information posted on the US Food and Drug Administration's website. J Manag Care Pharm 2012;19:72-3.

19 Marchand HC, Ros BJ, Fine AM, Kremzner ME. The US Food and Drug Administration drug information resource for formulary recommendations. J Manag Care Pharm 2012;18:713-8.

20 Navarro RP. Rediscovering FDA websites. J Manag Care Pharm 2012;18:719-20.

21 Ohmer J, Miller JW, Sasich LD. Accessing FDA approval packages and briefing documents. Ann Pharmacotherapy 2007;41:2071-2.

22 Food and Drug Administration. Executive summary of the Food and Drug Administration's consumer roundtable on consumer protection priorities. 2000.

23 Turner EH. Posting FDA new drug application reviews. JAMA 2007;298:863-4.

24 Jefferson T, Jones MA, Doshi P, Del Mar CB, Heneghan CJ, Hama R, Thompson MJ. Neuraminidase inhibitors for preventing and treating influenza in healthy adults and children. Cochrane Database Syst Rev 2012;1:CD008965.

25 Zarin DA, Tse T. Moving toward transparency of clinical trials. Science 2008;319:1340-2.

26 Schroll J. Deaths in trials should always be reported. BMJ 2013;347:44219.

Accepted: 22 August 2013

Cite this as: BMJ 2013;347:f5992

(c) BMJ Publishing Group Ltd 2013 


\section{Figures}

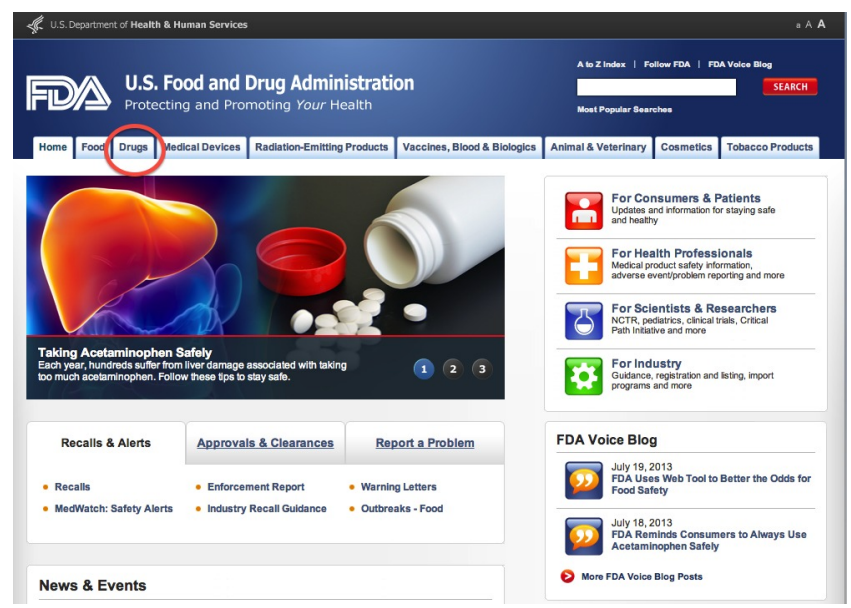

Fig 1 Screenshot of FDA homepage

FDA

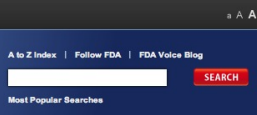

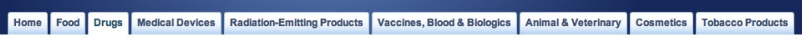
Drugs
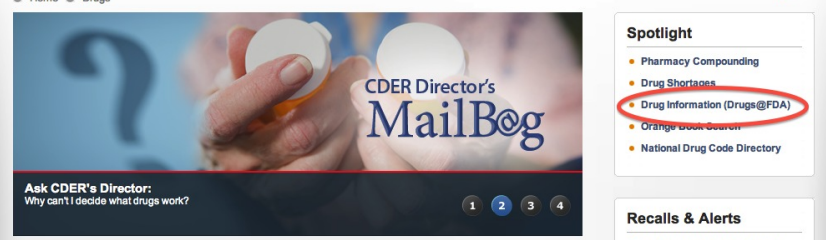

Recalls \& Alerts

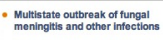

Navigate the Drugs Section

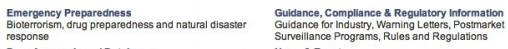

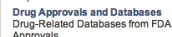

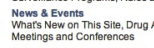

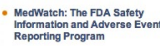

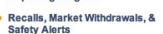

Fig 2 Homepage of Center for Drug Evaluation and Research

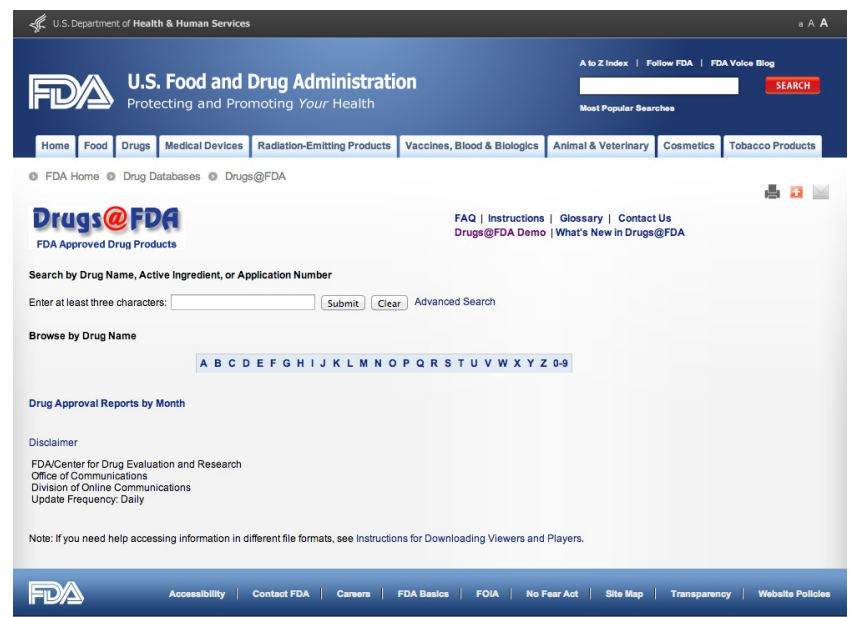

Fig 3 Main search page, Drug@FDA 


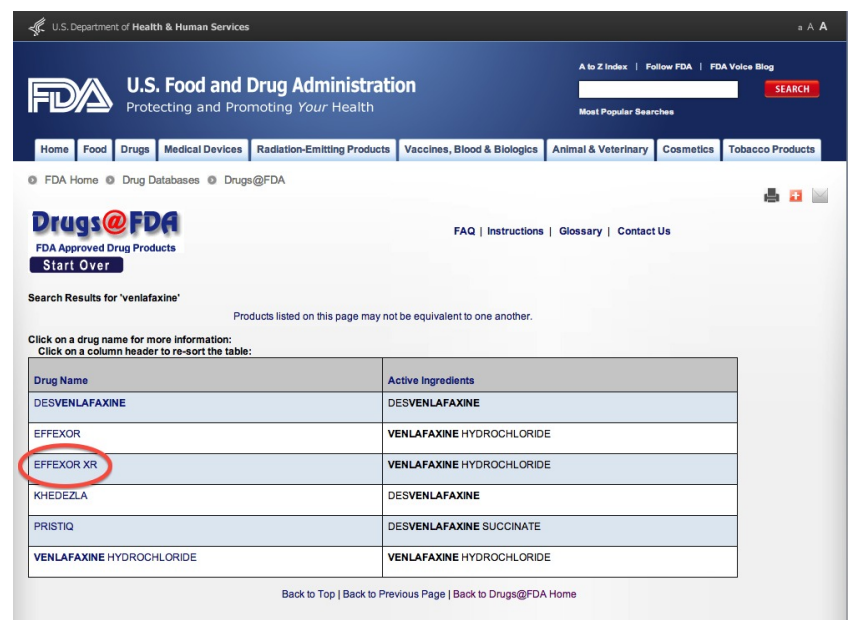

Fig 4 Search results for example drug

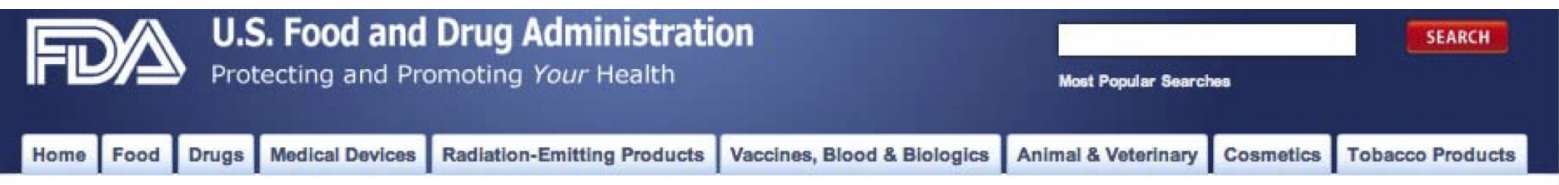

- FDA Home o Drug Databases o Drugs@FDA

\section{Drugs@FDA}

FDA Approved Drug Products

\section{Start Over Back to Search Results}

\section{Drug Details}

Drug Name(s)

FDA Application No.

Active Ingredient(s)

Company

Original Approval or Tentative Approval Date

Chemical Type

Review Classification
FAQ | Instructions | Glossary | Contact Us

GEmail Link 


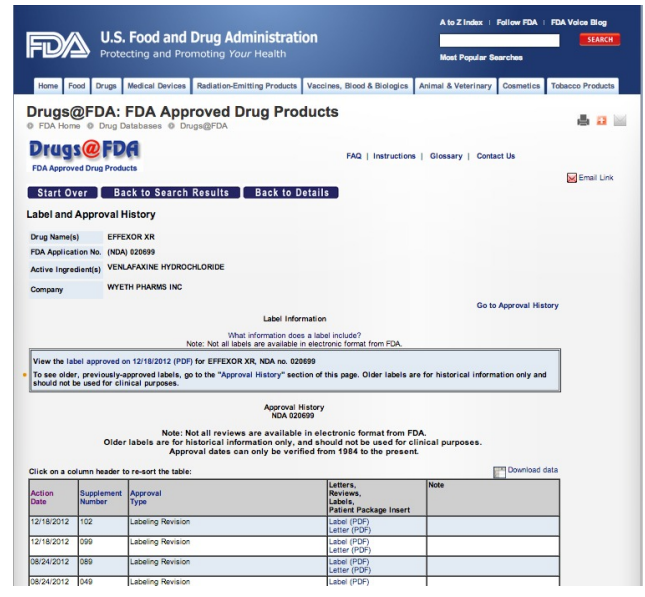

Fig 6 Approval history page

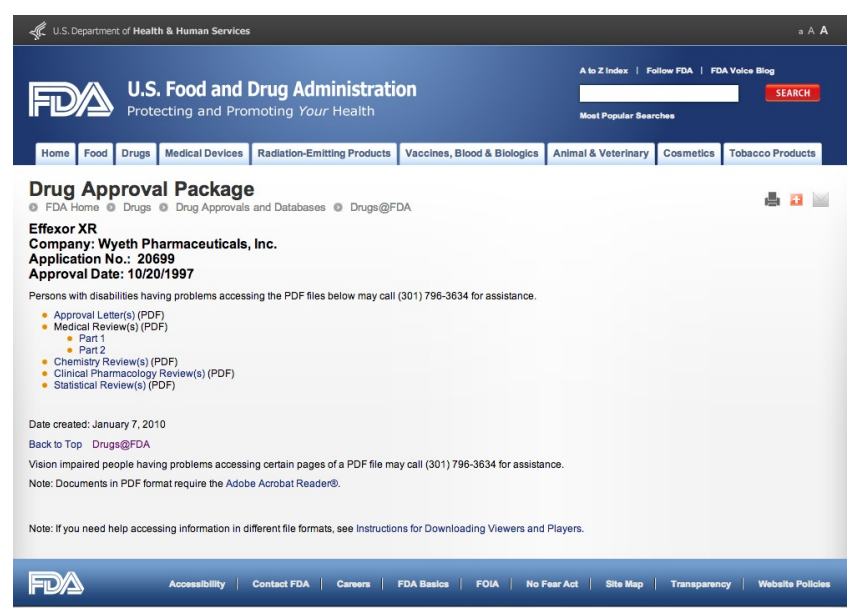

Fig 7 Drug approval package with links for downloadable reviews 
APPEADIX 5.1.1.1 Table of All studies

\begin{tabular}{|c|c|}
\hline $\begin{array}{l}6008-127-08 \\
23446\end{array}$ & 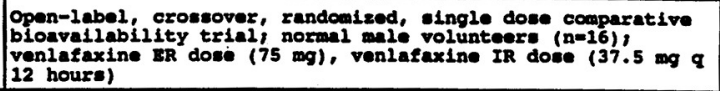 \\
\hline $\begin{array}{l}6008-134-0 s \\
24775\end{array}$ & 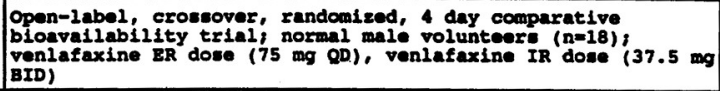 \\
\hline $\begin{array}{l}\text { 6008-136-0s } \\
26141\end{array}$ & $\begin{array}{l}\text { Open-1abel, crossover, randomized, } 4 \text { day multiple dose } \\
\text { relative bioavailability study, normal malie and female } \\
\text { volunteers (n=24); venlafaxine BR doses (75 } \mathrm{mg} \text { BID and } 150 \\
\text { mg OD); venlafaxine IR } 3 \text { day titration on } 37.5 \text { mg BID and } 75 \\
\text { mg BID }\end{array}$ \\
\hline $\begin{array}{l}6008-138-0 S \\
25771\end{array}$ & $\begin{array}{l}\text { Open-1abel, randomized, crossover; ingle dose food effect } \\
\text { (fed/fast); normal male volunteere }(\mathrm{n=12)} \text {, venlafaxine } \mathrm{ER} \\
\text { dose (75 mg) }\end{array}$ \\
\hline $\begin{array}{l}6008-143-\sigma_{R} \\
26760\end{array}$ & 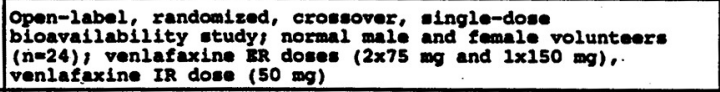 \\
\hline $\begin{array}{l}\text { 6008-144-FR } \\
26761\end{array}$ & 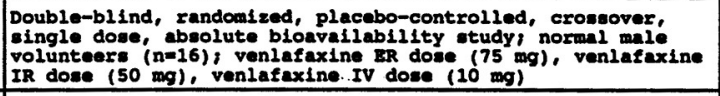 \\
\hline $\begin{array}{l}6008-145-U S \\
26787\end{array}$ & 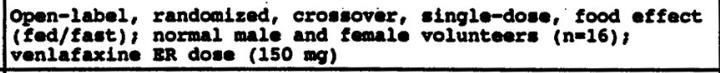 \\
\hline $\begin{array}{l}6008-139-0 s \\
25880\end{array}$ & $\begin{array}{l}\text { Open-1abel, randomized, 4-day crossover; } \mathrm{AM} \text { vE PK; normal } \\
\text { male volunteors (n=18); venlafaxine } \mathrm{ER} \text { doee }(75 \mathrm{mg} / \mathrm{day} \text { AM } \\
\text { doee, } 75 \mathrm{mg} / \text { day } \mathrm{PM} \text { dose) }\end{array}$ \\
\hline $\begin{array}{l}\text { 600B-101-JA-ER } \\
\text { Progrens report } \\
\text { in gubmisaion }\end{array}$ & $\begin{array}{l}\text { Double-blind, placebo-controlled, ascending single dose } \\
\text { tolerance and pharmacokinetics, normal subjects (n=32 } \\
\text { planned); venlafaxine ER doses (37.5 mg, } 75 \mathrm{mg}, 150 \mathrm{mg}, 225 \\
\text { mg). }\end{array}$ \\
\hline Phase 3 studies & - Controlled studies in Depression \\
\hline 6008-208-08 & 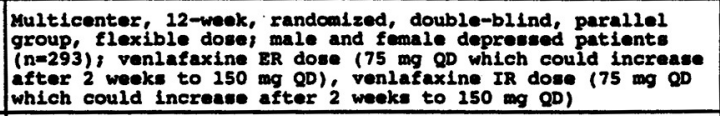 \\
\hline $\begin{array}{l}\text { 6008-209-US } \\
27258\end{array}$ & 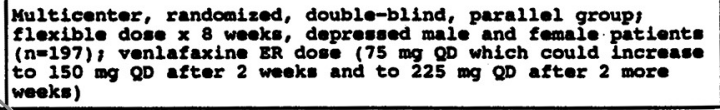 \\
\hline $6008-367-80$ & 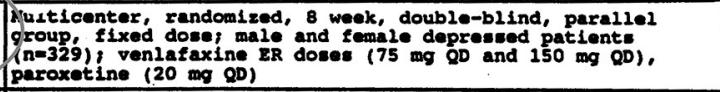 \\
\hline $\begin{array}{l}\text { 600B-211-08 } \\
\text { Prograes report } \\
\text { in uubaimaion }\end{array}$ & 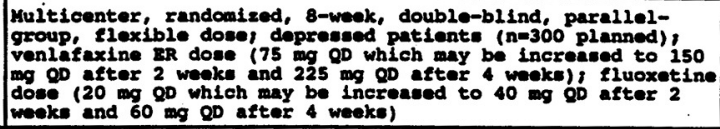 \\
\hline $\begin{array}{l}600 B-360-c \lambda \\
\text { Progrese report } \\
\text { in aubeniesion }\end{array}$ & 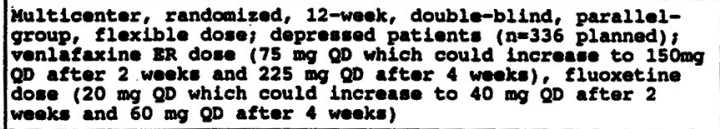 \\
\hline Phese 38 Uncont & colled studies in Dopression \\
\hline $6008-365-80$ & 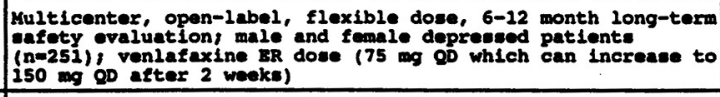 \\
\hline 600B-369-0s & 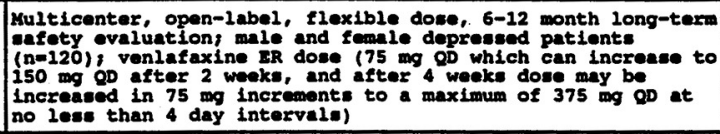 \\
\hline Phase 38 8tudise & In Generalized Anxiety Disorder \\
\hline $\begin{array}{l}6008-210-0 s \\
\text { Progreses report } \\
\text { in eubmission }\end{array}$ & 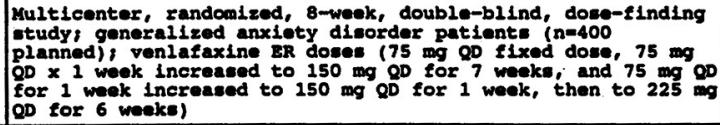 \\
\hline
\end{tabular}

Fig 8 Table of studies on Effexor XR 
TABEL 3.3 .3

367- 200

PRIMARY EFFICACY VARIABLES: PAIR WTSE COMPARISONS OF ADIUSTED MEANS LOCF ANALYSIS

\begin{tabular}{|c|c|c|c|c|c|c|c|}
\hline Time & Compariso & & Difference & SEM & $95 \times \mathrm{CL}$ & $\begin{array}{l}\text { Forest } \\
\text { p-Value }\end{array}$ & $\begin{array}{l}\text { Pairwise } \\
\text { p-Value }\end{array}$ \\
\hline \multicolumn{8}{|c|}{ RAM-D TOTAL SCORE } \\
\hline Weak ! & $\begin{array}{l}\text { Placebo } \\
\text { Placebo } \\
\text { Plucebo } \\
\vee 75 \mathrm{mg} \\
V 75 \mathrm{mg} \\
V 150 \mathrm{mg}\end{array}$ & $\begin{array}{l}\text { vs } V 75 \mathrm{mg} \\
\text { vs } V 150 \mathrm{mg} \\
\text { vs Paroxetine } \\
\text { vs } V 150 \mathrm{mg} \\
\text { vs Paroxetine } \\
\text { vs Paroxetine }\end{array}$ & $\begin{array}{r}1.7 \\
-0.3 \\
-0.0 \\
-2.0 \\
.1 .8 \\
0.2\end{array}$ & $\begin{array}{l}0.8 \\
0.9 \\
0.8 \\
0.9 \\
0.8 \\
0.9\end{array}$ & $\begin{array}{l}(0.1 .3 .4) \\
(-2.0 .1 .4) \\
(-1.7 .1 .6) \\
(-3.7 .-0.4) \\
(-3.4 .0 .2) \\
(-1.3 .1 .9)\end{array}$ & 0.057 & $\begin{array}{l}0.035 \\
0.74 \\
0.96 \\
0.018 \\
0.033 \\
0.78\end{array}$ \\
\hline Week 2 & $\begin{array}{l}\text { Placebo } v \\
\text { Placebo } v \\
\text { Placebo } \\
v 75 \mathrm{mg} \\
v 75 \mathrm{mg} \\
V 150 \mathrm{~ms}\end{array}$ & $\begin{array}{l}\text { vs } V 75 \mathrm{mg} \\
\text { vs } V 150 \mathrm{mg} \\
\text { vs Paroxetine } \\
\text { vs } V 150 \mathrm{mg} \\
\text { vs Paroxetine } \\
\text { vs Paroxetine }\end{array}$ & $\begin{array}{r}1.8 \\
0.9 \\
-1.0 \\
-0.8 \\
-2.8 \\
-1.9\end{array}$ & $\begin{array}{l}1.1 \\
1.2 \\
1.2 \\
1.2 \\
1.2 \\
1.2\end{array}$ & $\begin{array}{l}(-0.5 .4 .0) \\
(-1.4 .3 .3) \\
(-3.3 .1 .3) \\
(-3.2 .1 .5) \\
(-5.1 .0 .5) \\
(-4.5 .0 .4)\end{array}$ & 0.097 & $\begin{array}{l}0.13 \\
0.44 \\
0.38 \\
0.48 \\
0.017 \\
0.11\end{array}$ \\
\hline Week 4 & $\begin{array}{l}\text { Placebo } \\
\text { Placebo } \\
\text { Piacebo } \\
V 75 \mathrm{mg} \\
V 75 \mathrm{~ms} \\
V 150 \mathrm{mg}\end{array}$ & $\begin{array}{l}\text { vs } \vee 75 \mathrm{~ms} \\
\text { vs } V 150 \mathrm{~ms} \\
\text { vs Paroxetine } \\
\text { vs } V 150 \mathrm{~ms} \\
\text { vs Paroxetine } \\
\text { vs Paroxetine }\end{array}$ & $\begin{array}{r}1.4 \\
2.1 \\
-1.6 \\
0.7 \\
-3.0 \\
-3.7\end{array}$ & $\begin{array}{l}1.4 \\
1.5 \\
1.4 \\
1.5 \\
1.4 \\
1.5\end{array}$ & $\begin{array}{l}(-1.4 .4 .2) \\
(-0.8,5.0) \\
(-4.4 .12) \\
(-2.2 .3 .6) \\
(-5.8 .0 .2) \\
(-6.6 .0 .8)\end{array}$ & 0.059 & $\begin{array}{l}0.32 \\
0.16 \\
0.26 \\
0.64 \\
0.035 \\
0.013\end{array}$ \\
\hline Weak 6 & $\begin{array}{l}\text { Placebo v } \\
\text { Placebo v } \\
\text { Placebo v } \\
v 75 \mathrm{mg} \\
v 75 \mathrm{mg} \\
V 150 \mathrm{mg}\end{array}$ & $\begin{array}{l}\text { vs } \vee 75 \mathrm{~ms} \\
\text { vs } V \text { is0 mg } \\
\text { vs Paroxetine } \\
\text { vs } V 150 \mathrm{mg} \\
\text { vs Paroxetine } \\
\text { vs Paroxetine }\end{array}$ & $\begin{array}{r}2.1 \\
1.9 \\
-2.4 \\
-0.1 \\
-4.4 \\
-4.3\end{array}$ & $\begin{array}{l}1.6 \\
1.7 \\
1.6 \\
1.7 \\
1.6 \\
1.7\end{array}$ & $\begin{array}{l}(-1.1,5.2) \\
(-1.3 .5 .2) \\
(-5.6,0.8) \\
(-3.4,3.1) \\
(-7.6,-1.3) \\
(-7.6,-1.0)\end{array}$ & 0.024 & $\begin{array}{l}0.20 \\
0.24 \\
0.15 \\
0.94 \\
0.006 \\
0.011\end{array}$ \\
\hline Week 8 & $\begin{array}{l}\text { Placebo v } \\
\text { Placebo v } \\
\text { Placebo v } \\
\text { V } 75 \text { mg } \\
\text { V } 75 \text { ms } \\
V 150 \text { ang v }\end{array}$ & $\begin{array}{l}\text { vs } \vee 75 \mathrm{mg} \\
\text { vs } V 150 \mathrm{~ms} \\
\text { vs Paroxetine } \\
\text { vs } V 150 \mathrm{mg} \\
\text { vs Paroxetine } \\
\text { vs Paroxetine }\end{array}$ & $\begin{array}{r}2.5 \\
1.6 \\
-2.1 \\
-0.9 \\
-4.7 \\
.3 .8\end{array}$ & $\begin{array}{l}1.7 \\
1.7 \\
1.7 \\
1.7 \\
1.7 \\
1.7\end{array}$ & $\begin{array}{l}(-0.7,5.8) \\
(-1.8 .5 .0) \\
(-5.4,1.2) \\
(-4.3 .2 .4) \\
(-8.0,-1.4) \\
(-7.2,-0.3)\end{array}$ & 0.032 & $\begin{array}{l}0.13 \\
0.35 \\
0.20 \\
0.59 \\
0.005 \\
0.032\end{array}$ \\
\hline Final on-thernpy & $\begin{array}{l}\text { Plecebo } \\
\text { Placebo } \\
\text { Placebo } \\
v 75 \mathrm{mg} \\
v 75 \mathrm{mg} \\
v 150 \mathrm{mg}\end{array}$ & $\begin{array}{l}\text { vs } V 75 \mathrm{mg} \\
\text { vs } V 150 \mathrm{mg} \\
\text { vs Paroxetine } \\
\text { vs } V 150 \mathrm{mg} \\
\text { vs Paroxetine } \\
\text { vs Paroxetine }\end{array}$ & $\begin{array}{r}2.6 \\
1.6 \\
-2.2 \\
-1.1 \\
4.8 \\
-3.7\end{array}$ & $\begin{array}{l}1.7 \\
1.7 \\
1.7 \\
1.7 \\
1.7 \\
1.7\end{array}$ & $\begin{array}{l}(-0.6 .5 .9) \\
(-1.8 .4 .9) \\
(-5.5 .(2) \\
(-4.4 .23) \\
(-8.0 .-1.5) \\
(-9.1 .0 .3)\end{array}$ & 0.029 & $\begin{array}{l}0.11 \\
0.37 \\
0.20 \\
0.53 \\
0.005 \\
0.034\end{array}$ \\
\hline
\end{tabular}

Fig 9 Table from FDA review showing non-significant results for unpublished study 